\title{
Effects of Spatial Crowding on Store Loyalty: Roles of Store Size
}

\author{
Yongsoo Ha ${ }^{1, *}$, Yuri Lee ${ }^{2}$ \\ ${ }^{1}$ Department of Consumer Science, Purdue University, USA \\ ${ }^{2}$ Department of Textiles, Merchandising, and Fashion Design/The Research Institute of Human Ecology, \\ Seoul National University, South Korea
}

Copyright $\mathrm{C} 2016$ by authors, all rights reserved. Authors agree that this article remains permanently open access under the terms of the Creative Commons Attribution License 4.0 International License

\begin{abstract}
Spatial crowding and social crowding are mutually distinctive dimensions of perceived crowding. This study investigates the sole effects of spatial crowding on store loyalty and the roles of store size in spatial crowding-store loyalty relationships. Two video clips which display different store size were recorded for the purpose of the study. An internet survey was conducted with 400 fashion brand consumers. A multiple group analysis was conducted using structural equation modeling. This study consists of three stages. The first stage tested the general effects of spatial crowding. Test results showed that, when social crowding was controlled, spatial crowding did not show negative impacts on pleasure, rather the relationship was positive. Pleasure showed positive impact on expectation and, subsequently, it led to store loyalty. Such results are opposed to a prevailing belief that retail store crowding results in negative retail outcomes. The second stage tested the role of store size. Density and social crowding were controlled as the same level in both small and large stores. In the large store, spatial crowding effected on pleasure positively, whereas, the effect was negative in the small store. The third stage revealed the mediating effect of perceived control, albeit partially. In the small store, the negative effects of spatial crowding on pleasure dropped in magnitude when perceived control was included as a mediator. Implications for practice and future research opportunities are discussed.
\end{abstract}

Keywords Spatial Crowding, Store Size, Store Loyalty, Pleasure, Expectation

\section{Introduction}

A store atmosphere has significant impacts on consumers' purchase decision [1]. It is believed to be more influential than products or service itself at the service encounter [1]. Retail store is a crucial component of store atmosphere [1]. It helps customers to expect of store service and generates perceptual images of store in customers' minds in an instant [1]. Physical environments of retail store affect every aspect of retailing business [2]. In this regard, retailers try to provide positive shopping experiences to their customers and enhance customers' store loyalty by managing store atmosphere [3]. This study is designed to test two fundamental factors of retail store atmosphere; retail store crowding and retail store size.

Perceived crowding refers to "a subjective state of psychological stress that arises from a situation of scarce space" [4]. As a component of store environment, retail store crowding influence on customers' overall shopping experience $[5,6]$. Spatial crowding and social crowding are two distinctive dimensions of perceived crowding [6]. Although there have been many research that investigated the impact of perceived crowding on consumers in a retail setting, most studies have not distinguished between spatial and social dimensions of crowding [2, 7-9]. An attempt to investigate the sole effects of spatial crowding has been widely neglected in previous retail crowding research. Moreover, considering that managing spatial dimensions of crowding (e.g., store size, product placement, fixtures) is more feasible for retailers than managing social dimensions of crowding (e.g., customers, sales personnel) [9], testing the sole effects of spatial crowding could suggest a practical implication for retailers. Thus, this study aims to test the sole effects of spatial crowding on store loyalty.

Although store size is an antecedent of overall levels of perceived crowding $[3,10]$, the impact of store size on spatial crowding has not been fully investigated yet. Individuals perceive the levels of crowding differently depending on situational settings, even though they are situated in the same density level $[11,12]$. Therefore, it is possible that the effects of spatial crowding on customers could be different according to the size of a retail store. In this regard, this study aims to test the roles of retail store size in spatial crowding-store loyalty relationships.

\section{Literature Review and Hypotheses Development}

This section reviews the theoretical backgrounds of the 
variables included in the proposed model; spatial crowding, pleasure, expectation, store loyalty, and perceived control.

\section{Spatial Crowding}

Perceived crowding is a subjective, psychological stress that occurs when the supply of space is less than individual's demand [4]. Individuals show emotional, cognitive, and behavioral responses to perceived crowding $[5,6,13,14]$. Perceived crowding acts as an integral element of store environment and functions as a determinant of customers' shopping experience $[5,6]$.

Stokols [4] stated that the concepts of density and crowding should be differentiated. Density is an objective environmental element of individuals' crowding experiences [15]. Density is about a physical condition that is related to spatial limitation rather than an experiential state. However, crowding is a subjective experience state of certain density level that entails negative outcomes [15]. Since density is a necessary antecedent of crowding experience, perceived crowding arises through the juxtaposition of density [4]. In order for the objective condition of restricted space to become aversive, physical, social, and personal factors should be activated. When individuals perceive such factors, the physical condition of density elicits the experiential state of crowding [12]. Even under the same density level, perceived crowding can vary according to its environmental settings [12]. For example, individuals in a high density bar perceive their physical condition as less crowded and less unpleasant, compare to those in a high density bank [14].

Machleit et al [6] stated that perceived crowding has two dimensions; spatial and social dimensions. Spatial crowding involves nonhuman elements in a given environment. The number of nonhuman elements and their interactions influence the spatial aspect of crowding. In a retail setting, customers perceive store environments as crowded when they feel difficulties in physical movement, due to a limited space, while they shop at stores. The number of merchandises and fixtures, and their configuration within the retail store affect the spatial dimension of perceived crowding. Whereas, social crowding involves the number of individuals and their interactions in a given environment. In a retail store, a large number of customers and sales personnel simultaneously participate in shopping and service activities cause high levels of social crowding [6,7]. Spatial and social dimensions of crowding are mutually distinctive and interact with each other to compose perceived crowding [4].

Although previous studies conducted on perceived retail crowding measured both dimensions of crowding separately [2, 7-9], there have been no attempt to investigate the sole effects of spatial crowding by controlling the influence of social crowding over spatial crowding. For example, in studies of Machleit et al [7] and Eroglu et al [9], respondents answered to a questionnaire after a short shopping trip at a store. Dion [8] and Li et al [2] conducted a field study and interviewed store customers about their perceived crowing. However, in these research settings, the interaction effects between spatial crowding and social crowding were not controlled, since the presented stores simultaneously included both dimensions of crowding. Therefore, considering the interaction effect between social and spatial crowding, the levels of density and social crowding should be controlled at the same level to test the sole effects of spatial crowding. Understanding the sole effects of spatial crowding is important in that it is easy for retailers to control nonhuman elements of stores, such as the number of merchandises or configuration of fixtures, rather than controlling the number of customers or sales personnel [9]. This study tests the sole effects of spatial crowding on customers by manipulating density and social crowding at the same level at both small and large stores.

\section{Responses to Perceived Crowding}

The levels of perceived crowding influence individuals' emotional, cognitive, and behavioral responses to a given environment $[5,6,13,14]$. Retail store crowding has an impact on customers' emotion and expectation toward the store, and subsequently effects on customers' buying decision and future patronage [5].

\section{Pleasure}

Emotion refers to "a deeply rooted, multidimensional construct that can be influenced through specific situations and events" $[16,17]$. Physical store environments influence customers' emotional state [1]. In a retail setting, the effects of perceived crowding on shopping experience can be mediated by customers' emotion [7].

Pleasure, the degree to which an individual feels happy and joyful in a place, is an emotion that has a strong effect on customers' shopping experience [18]. Mehrabian and Russell [18] revealed that pleasure produces the most direct and strongest impact on customers' approach-avoidance behavior among the three emotional dimensions; pleasure-displeasure, dominance-submissiveness, arousal-unarousal. Perceived crowding produces an impact on emotion. In a study of Machleit et al [7], perceived crowding decreases positive feelings and/or increases negative feelings. Hui and Bateson [14] tested the effects of perceived crowding in a service environment. In their study, participants reported less pleasant as the levels of crowding increase [14]. Although the relationship between perceived crowding and pleasure has been investigated, the sole effects of spatial crowding on pleasure have not been tested yet. This study aims to contribute to retail crowding research by identifying the sole effects of spatial crowding on store loyalty. The results of the study also can provide practical implications for retailers with respect to the way of controlling the amount of products in stores and managing store configuration.

In light of this discussion, the first hypothesis of the study is that

H1: Spatial crowding will negatively influence pleasure. 


\section{Expectation}

Individuals perceive a given environment as crowded when their physical activities within a limited space are restrictive due to the number of people and/or objects [7]. Once individuals perceive crowding, they try to alleviate the recognized disparity imposed by spatial limitations [8]. In order to minimize perceived restriction, individuals respond to the situation through either cognitively adjusting personal factors or behaviorally augmenting their situated spatial supply [4]. Cognitive responses to perceived crowding involve adjusting the standard of spatial adequacy, enhancing the attractiveness of the task, or building a positive expectation toward the task.

Oliver [20] stated that expectation formation is a cognitive process. Customer expectation is a pretrial belief about a product or a service [21]. Customers form expectation about an overall shopping experience (e.g., product assortment, merchandise quality, and/or upcoming service encounters) prior to their actual purchase [21]. Store atmosphere influences expectation formation about a particular store [20]. Expectation functions as a baseline of satisfaction/dissatisfaction judgement and influences customers' future purchase decision [21]. However, despite its importance, the effects of customer expectation have been ignored in store atmosphere study $[20,22]$. Although it is controvertible, whether emotion precedes cognition or vice-versa, an emotion has been believed to be an antecedent of cognition in retail studies [22].

Thus, the second hypothesis of the study is that

H2: Pleasure will positively influence expectation toward the store.

\section{Store Loyalty}

Store loyalty refers to "a conscious buying behavior of a consumer expressed over time, with respect to one specific store out of a set of stores" [23]. Store commitment and buying behavior are two constructs that constitute store loyalty [24]. Store commitment is a persisting desire of consumers which intends to maintain a relationship with a particular store [25]. Without store commitment, store patronage behaviors are directed by inertia [26]. Since store loyalty is driven by store commitment, customers without store commitment only spuriously loyal to the store [26]. As the other construct of store loyalty, buying behavior refers to a customers' current and future purchase behavior related to a particular store [27].

Store loyalty is influenced by customer expectation both directly and indirectly [28]. Customer expectation affects store loyalty through each construct of store loyalty. For example, positive expectation toward the store enhances store commitment [28]. Moreover, customers who have a positive expectation toward a store tend to engage in buying behaviors that are beneficial to the store, such as generating and spreading positive word-of-mouth, recommending the store to other customers, and/or repeating their purchase only at the particular store [21].
Thus, the third hypothesis of the study is that

H3: Expectation will positively influence store loyalty.

\section{Store Size}

Store size, the size of space for customers, merchandises and fixtures, is a direct determinant of overall perceived crowding in a retail store $[3,10]$, and it enhances customers' store patronage behavior [29]. Retailers use two of contrasting store size strategies according to store location, product category, or the levels of rent payment [10]. Retailers located in metropolitan area who are competing in highly saturated market tend to use small store strategy to deal with high expenses. However, retailers dealing with broad and deep mix of merchandises tend to use large store strategy. Retailers using large store strategy try to dominate smaller stores with size, and try to be distinctive by using their store as a marketing tool [10].

Considering that retailers establish different store size strategies with respect to their diverse marketing mix, and customers expect different values and respond to the store environment differently according to the size of stores $[10$, 29], the role of store size is important in customers' shopping experience.

Thus, the fourth hypothesis of the study is that

H4: The effects of spatial crowding on store loyalty will differ according to store size.

H4a: The effects of spatial crowding on pleasure will differ according to store size.

H4b: The effects of pleasure on expectation will differ according to store size.

H4c: The effects of expectation on store loyalty will differ according to store size.

\section{Perceived Control}

Control refers to "a need to demonstrate one's competence, superiority, and mastery over the environment" [30]. It is a belief that individuals have at their response and disposal which have an influence on events [31]. When individuals perceive control over their situated environments, they tend to feel and behave more positively than when they perceive less control over the environment [32]. With heightened control, individuals become capable of anticipating events and preparing themselves for appropriate coping mechanisms [33].

Perceived control is a crucial factor that has an impact on service experiences in that it influences the quality of interactions between customers and store environment $[14$, 34]. In a service encounter, perceived control mediates customers' emotional and behavioral responses to store environments [14]. Customers achieve control in a retail store when they are provided with store-related information (e.g., store layout, product assortment) [35]. Customers also can obtain control through architectural and interior design of the store [36]. Hui and Bateson [14] revealed that perceived control alleviates negative outcomes of high density in a retail store. Dion [8] found that customers with high levels of control perceive store environment as less crowded. 
Thus, the fifth hypothesis of the study is that

H5: Perceived control will mediate the relationship between spatial crowding and pleasure.

In testing $\mathrm{H} 5$, considering that the purpose of giving control back to customers is minimizing negative outcomes of perceived crowding, the mediating effects of perceived control will be tested only when spatial crowding shows negative impacts on pleasure.

\section{Method}

\section{Methodology}

A survey based empirical study with 400 respondents was conducted using within subject design. This study consists of three stages. First stage is to test the effects of spatial crowding on store loyalty. In the second stage, all samples are divided into two separate groups according to store size, and analyzed through multiple group analysis to test the effects of store size. Third stage is to test the mediating effect of perceived control. The third stage will be tested only when a spatial crowding shows negative impact on pleasure in the second stage.

Considering that the aim of this study is to test the sole effects of spatial crowding and the size of a store, it is crucial to control both density and social crowding at the same level in all research conditions. In this regard, we recorded two video clips for the purpose of the study. Video-recording methods have proved effective for environmental representations of various settings such as retail and service situations [37]. Marketing and consumer researchers have used video-recording methods to study customers' response to shopping and retail environments at the point of sale [38]. The use of video-recording methods enables researchers to examine the impact of diverse store environmental situations on customers, in a relatively easy, inexpensive, and realistic way [39]. For example, Baker et al [40] recorded four versions of a retail store, as customers walking through the store, to test the effects of store atmospheric factors on customers' purchase intension. Baker et al [37] used video-recording methods to test the influence of multiple store environment cues on customers' perceived merchandise value and patronage intentions. In their study, subjects completed a survey questionnaire after they watched a video which simulates a shopping and browsing experience. Bateson and Hui [41] used video-recording method to simulate service settings and to manipulate consumer density. Their study revealed that watching videos did evoke the same psychological and behavioral reactions from participants, as they might have in actual service settings.

In the present study, videos were recorded at two fashion retail stores with neither sales personnel nor customers.
Thus, a social crowding was controlled as zero in both stores. Density was rigorously controlled by the brand as a way of merchandising strategy. The two stores were managed by the same brand, which displayed the same sort of merchandises, and contained the same number of products in a given area. These two stores are basically identical in their service offerings, thus, only the store size and accompanied spatial crowding were manipulated differently in the two videos. The large store was more than 6.6 times larger than the small store. The size of the small store was $1,776 \mathrm{ft}^{2}$ and the size of the large store was 11,743 $\mathrm{ft}^{2}$. A pretest indicated that the size of the small store versus large store was successfully manipulated in the two videos. The length of each video was 88 seconds for the small store and 87 seconds for the large store.

The survey was conducted on-line, in 2012, in South Korea, with consumers who have had experiences of purchasing products at the same store presented in the video. Participants were randomly divided into two groups and watched videos of the whole view of the small store and the large store. The videos were presented as customers walk through the stores, rotating clockwise. In presenting the videos, half of the participants saw the video of the small store first and the other half saw the video of the large store first to control order effect. Questions on a fashion-involvement were inserted between the two videos so as to control the persistence of vision occurring in case of presenting the videos successively. Participants were asked to think of themselves as if they were in real buying situations while watching the videos, and they answered to questionnaire items after watching both videos.

\section{Measures}

The conceptual framework of this study combined two of the established models: retail crowding model [9] and retail approach-avoidance behavior model [19]. A self-administered questionnaire measured the five dependent variables: spatial crowding, pleasure, expectation, store loyalty, and perceived control.

All measurement scales were adapted from established scales and measured with 7-point Likert scale. Eighteen items were used in the tested model as shown in Table 1. Spatial crowding was measured using three items validated by Hui and Bateson [14]. Pleasure was measured using six items developed by Donnovan and Rossiter [19]. Expectation was measured using three items developed by Gagliano and Hathcote [42]. Store loyalty was measured using four items; two items for store commitment [43] and two items for buying behavior [44]. Perceived control was measured using two items developed by Langer and Saegart [45]. 
Table 1. Observed variables, standardized loadings, reliability statistics for construct measures

\begin{tabular}{|c|c|c|c|}
\hline $\begin{array}{c}\text { Latent } \\
\text { Variable }\end{array}$ & Observed Variable & $\begin{array}{l}\text { Standardized } \\
\text { Loading }\end{array}$ & Cronbach's a \\
\hline \multirow{3}{*}{$\begin{array}{c}\text { Spatial } \\
\text { Crowding }\end{array}$} & I felt crowded when I was looking around the store & 0.69 & \multirow{3}{*}{0.755} \\
\hline & I felt easy to move when I was looking around the store (reverse) & 0.63 & \\
\hline & I felt confined because there were too many fixtures in the store & 0.70 & \\
\hline \multirow{6}{*}{ Pleasure } & Unhappy - Happy & 0.89 & \multirow{6}{*}{0.925} \\
\hline & Unsatisfied - Satisfied & 0.85 & \\
\hline & Unpleasant - Pleasant & 0.79 & \\
\hline & Depressed - Vibrant & 0.86 & \\
\hline & Boring - Interesting & 0.88 & \\
\hline & Restrictive - Free & 0.85 & \\
\hline \multirow{3}{*}{ Expectation } & Products in this store may have a good quality & 0.65 & \multirow{3}{*}{0.729} \\
\hline & This store may have many trendy products & 0.63 & \\
\hline & Display in this store will be refined & 0.67 & \\
\hline \multirow{4}{*}{$\begin{array}{c}\text { Store } \\
\text { Loyalty }\end{array}$} & I want to purchase a product in this store & 0.60 & \multirow{4}{*}{0.747} \\
\hline & I want to browse this store & 0.85 & \\
\hline & I will visit this store again & 0.62 & \\
\hline & I will recommend this store to others & 0.64 & \\
\hline \multirow{2}{*}{$\begin{array}{c}\text { Perceived } \\
\text { Control }\end{array}$} & $\begin{array}{c}\text { I felt like I controlled the situation } \\
\text { when I was looking around the store and made a decision }\end{array}$ & 0.78 & \multirow{2}{*}{0.718} \\
\hline & $\begin{array}{l}\text { I was aware of how crowded this store would be } \\
\text { before looking around the store }\end{array}$ & 0.59 & \\
\hline
\end{tabular}

Table 2. Pairwise parameter comparison

\begin{tabular}{|c|c|c|c|c|}
\hline & & \multicolumn{3}{|c|}{ Large Store } \\
\hline & & $\begin{array}{c}\text { Spatial Crowding } \rightarrow \\
\text { Pleasure }\end{array}$ & Pleasure $\rightarrow$ Expectation & Expectation $\rightarrow$ Store Loyalty \\
\hline \multirow{3}{*}{ Small Store } & $\begin{array}{c}\text { Spatial Crowding } \rightarrow \\
\text { Pleasure }\end{array}$ & 8.758 & & \\
\hline & Pleasure $\rightarrow$ Expectation & & -6.945 & \\
\hline & $\begin{array}{c}\text { Expectation } \rightarrow \text { Store } \\
\text { Loyalty } \\
\end{array}$ & & & -2.116 \\
\hline
\end{tabular}

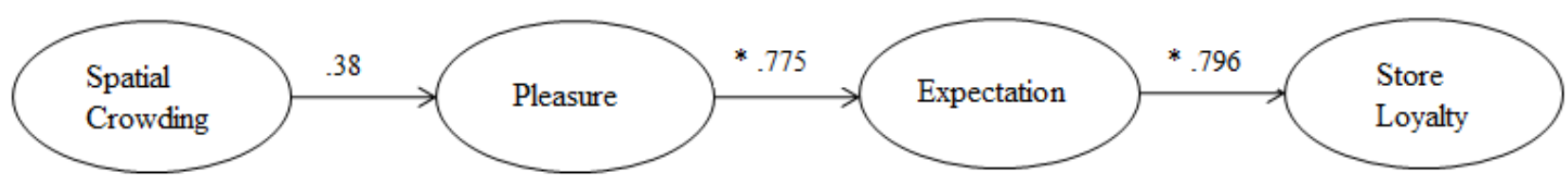

$\mathrm{X}^{2} / \mathrm{df}=1.79 ; \mathrm{GFI}=0.841 ; \mathrm{AGFI}=0.774 ; \mathrm{RMSEA}=0.063(\mathrm{p}<0.05)$

Figure 1. Results: Estimated model

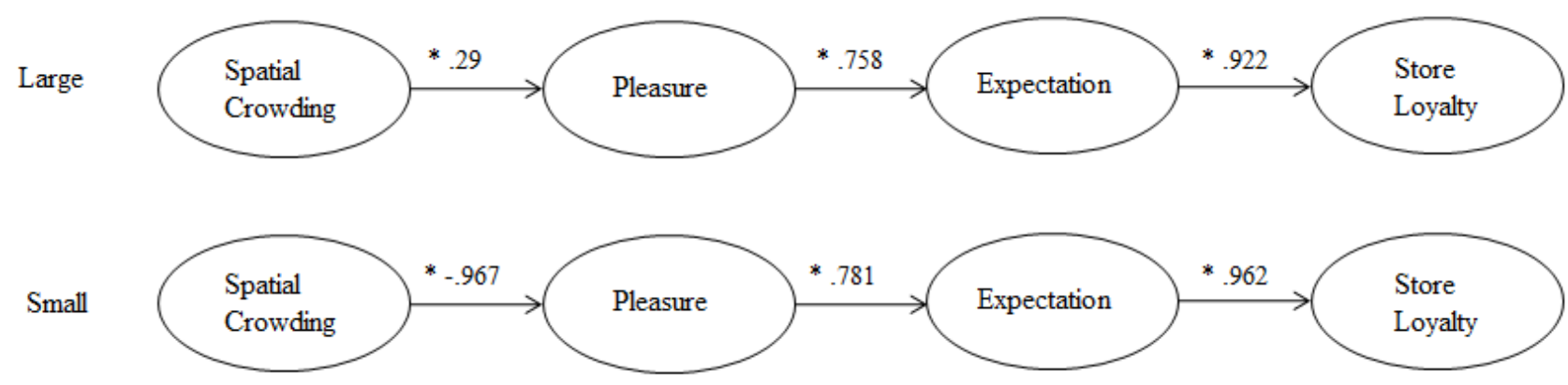

Figure 2. Results: Estimated model for multiple group analysis 


\section{Data Analysis and Results}

The data was analyzed through structural equations modeling using AMOS 20. In the first stage, the effects of spatial crowding on store loyalty were analyzed through a two-step structural equation modeling approach [46]. A multiple group analysis was conducted in the second stage to test the effects of store size. Mediating effects of perceived control was tested in the third stage following Baron and Kenny's [47] steps for mediation.

As a result of confirmatory factor analysis, among the 21 items included in the original model, three items were excluded. All of the eighteen items in the revised model, loaded appropriately on the one-dimensional measure, ranging from 0.59 to $0.89(\mathrm{p}<0.05)$. Coefficient alpha reliability values for each variables were greater than 0.7 (Table 1). These figures indicate that the CFA model for this study fits well with the empirical data [48].

As CFA was confirmed, the effects of spatial crowding on store loyalty, $\mathrm{H} 1$ through $\mathrm{H} 3$, were tested in stage 1 . The measurement model showed an acceptable model fit. A chi-square ratio to degrees of freedom was 1.79 , a goodness of fit index (GFI) was 0.841, an adjusted goodness of fit index was 0.774 , and a root mean square error of approximation (RMSEA) was 0.063 . Among the three paths in the model, the effects of pleasure on expectation (H2) and the effects of expectation on store loyalty (H3) were significant $(\mathrm{p}<0.05)$ (Figure 1). However, the effects of spatial crowding on pleasure $(\mathrm{H} 1)$ were not significant, indeed the relationship was positive. Thus, $\mathrm{H} 1$ was not supported. $\mathrm{H} 2$ and $\mathrm{H} 3$ were supported.

The second stage was conducted to test the effects of store size (H4). To test $\mathrm{H} 4$, the measurement model was divided into two separate models, small store $(\mathrm{N}=400)$ and large store $(\mathrm{N}=400)$ models, to conduct a multiple group analysis. A multiple group confirmatory factor analysis was conducted to test cross validation for both models. Chi-square differences of unconstrained model and measurement weights-constrained model was 17.080(13), which was smaller than $22.36(p>0.05)$. Thus, the test results indicate that instruments of this study were statistically appropriate for the use of multiple group analysis.

Multiple group analysis was conducted with two models. Multiple group comparison was accomplished by running separate path analysis for both groups, then comparing the path estimates of each pair. Figure 2 presents the test results. All the absolute fit measures indicate that the model was acceptable $\left(\mathrm{x}^{2} / \mathrm{df}=2.62 ;\right.$ GFI $=0.857$; AGFI $=0.842$; RMSEA $=0.073$ ). All of the three paths in the model were significant in both the small store $(p<0.05)$ and the large store $(p<0.1)$. Notably, spatial crowding affected pleasure negatively in the small store (-.967), whereas, the effects of spatial crowding on pleasure was positive in the large store (.290). Finally, pairwise parameter comparison of each store showed that all of the three paths in the model were significantly different in $\mathrm{p}<0.05$ level. All critical ratio differences were greater than \pm 1.965 (Table 2). Thus, we can conclude that all of three relationships in the model were statistically different according to store size. Therefore, $\mathrm{H} 4 \mathrm{a}, \mathrm{H} 4 \mathrm{~b}$, and $\mathrm{H} 4 \mathrm{c}$ were supported.

The third stage tested the mediating effects of perceived control in a relationship between spatial crowding and pleasure. The second stage of the study revealed that the impact of spatial crowding on pleasure was positive in the large store, whereas, negative in the small store. Since the aim of providing control to customers is to minimize negative outcomes of perceived crowding, the mediating effect of perceived control was tested only in the small store. All three paths related to perceived control were significant in the small store model; spatial crowding-pleasure (-.967), spatial crowding-perceived control (-.372), and perceived control-pleasure (.901) $(\mathrm{p}<0.05)$. Although there were some minor changes in the figures with perceived control variable included in the model, all fit measures were still remained acceptable $\left(\mathrm{x}^{2} / \mathrm{df}=2.07 ;\right.$ GFI $=0.842 ;$ AGFI $=0.792$; RMSEA $=0.071)$. When perceived control was included as a mediator between the two variables, spatial crowding and pleasure, the negative effects of spatial crowding on pleasure dropped in magnitude (from -.967 to -.343), but the effects were still remained significant $(\mathrm{p}=.014)$. Thus, we can conclude that perceived control only partially mediates the negative effects of spatial crowding on pleasure [47]. Therefore, $\mathrm{H} 5$ was partially supported.

\section{Discussion and Implication}

The results of this study revealed the effects of spatial crowding on store loyalty and the roles of store size in a spatial crowding-store loyalty relationship.

In stage 1, the sole effects of spatial crowding were tested by controlling the effects of density and social crowding. The findings of the first stage are opposed to the common beliefs of crowding that retail store crowding leads to negative retail outcomes [7]. When controlling social crowding, spatial crowding did not show negative effects on pleasure, rather the relationship was positive. Since the sole effects of crowding did not reveal negative impacts on store loyalty, the results suggest that the social dimension of crowding and the interplay between spatial and social crowding mostly generate negative outcomes of retail crowding. This result is meaningful in that previous researches conducted on retail crowding have not controlled the interaction effects between the two dimensions of crowding.

Pleasure showed positive impact on expectation and, subsequently, it led to store loyalty. The results suggest that if retailers generate the pleasant feelings of customers by managing the levels of spatial crowding according to the size of a store, customers form positive expectations toward not only a product but also a service of the store [21], and eventually, those positive expectations lead to store loyalty. 
Suggestions for managing the levels of spatial crowding will be discussed in the next paragraph particularly for each size of the store.

In stage 2, the roles of store size in a spatial crowding-store loyalty relationship were revealed. Three relationships were tested in this study; spatial crowding-pleasure, pleasure-expectation, and expectation-store loyalty. Among the three relationships, the effects of pleasure and expectation occurred in a similar fashion in both small and large stores. Although the degree of effects was significantly different, the relationships were positive in both stores. Pleasure showed positive impacts on expectation and, subsequently, it led to store loyalty in both stores. However, notably, the relationship between spatial crowding and pleasure was different between the two stores. The relationship was positive in the large store, whereas, negative in the small store. This means that even though they are in the same density and social crowding levels, customers' subjective psychological state of crowding could be different according to store size. The results that spatial crowding shows positive effects on pleasure in the large store can be attributed to the product type used in the current study. The stores presented in the video clips were fashion retail stores which deal in relatively discounted, low-involvement products. When they shop for such low-involvement products, customers tend to rely on heuristic information processing [49]. Thus, in the large store, especially when they shop for low-involvement products, customers might infer the popularity of the store or the diversity of product assortments in the store from the spatially crowded store environment, and it could generate positive emotional responses.

The results suggest that retailers should differentiate in merchandising strategies according to their store size approach. In large stores, customers feel pleasant from spatially crowded shopping environment. They form positive expectations toward the store (e.g., diversity of merchandise, quality of products, processing of the service), and, eventually, it leads to store loyalty. Thus, retailers using large store approach should maintain certain levels of spatial crowding to generate pleasant shopping atmosphere. Considering that large spaces introduce feelings of isolation and results in less than optimal stimulation for subjects [50], displaying numerous merchandises with diverse product assortments in a store can help to meet optimum spatial crowding levels in large stores. Placing fixtures in store also can increase the levels of spatial crowding. For example, placing aisle tables in store creates more spatial crowding in parallel with attracting shoppers' attention and leading them to unplanned impulse purchases [2]. However, in small stores, even though density and social crowding are controlled as same as large stores, customers find it easy to perceive the environment as more crowded, and thus, it generates negative emotional responses. Therefore, store configuration in a small store should be arranged in a way that it could be perceived as less crowded than it actually is. Partitioning an enclosed space or making linear dimensions of a room more disparate [11] could be a merchandising strategy to overcome spatial crowding owing to a limited space. Retailers using small store approach could be more enthusiastic to alleviate unpleasant feelings derived from spatially crowded environments. Displaying only a limited amount of merchandises can directly reduce the levels of density and the accompanied levels of spatial crowding while inducing customers to focus on few key products.

In stage 3 , the mediating effect of perceived control was tested. The mediating effect of perceived control was tested only in the small store since spatial crowding showed positive impact on pleasure in the large store. The results suggest that perceived control can contribute to a more pleasant service environment. Although the mediating effect was not significant enough, the negative effects of spatial crowding on pleasure dropped in magnitude when perceived control included as a mediator in the model. Dion [8] revealed that informational control is the most effective type of control among the three sources of personal control (e.g., behavioral, decisional, and informational control). Customers with better information on the store environment can anticipate difficulties and prepare themselves. Thus, in a small store, it is recommended to inform customers on affluence of products in a store to help them be aware of spatially crowded store environment, and to enhance their perceived control.

\section{Limitations and Future Research}

There are some limitations in the present study.

Future research should consider various factors that affect store loyalty. In particular, product involvement is a variable that has the potential of moderating the effects of spatial crowding on store loyalty. Product involvement is a perceived relevance of individual products to customers [51]. When customers shop for high-involvement products, they display extensive information-seeking behavior [52], and spend more time and effort in information processing to draw inferences [53]. Moreover, high involvement enhances the impact of information on attitude, and it also increases the impact of attitude on loyalty [54]. Considering that customers who are seeking for high involvement products need more physical and psychological spaces to assess their purchase decision [55], the effects of spatial crowding and/or store size on store loyalty could be different according to the involvement of products. However, this study only obtained data from customers of a fashion retail store which sells relatively low involvement products. Thus, future research on retail crowding should deal with both low and high involvement products.

Satisfaction is another factor that should be considered in future research to test store loyalty, especially when the research deals with high involvement products. Since the present study tested sore loyalty only with low involvement products, the role of satisfaction in the relationship between spatial crowding and store loyalty was not investigated. 
According to Bloemer and Poiesz [56], customers engaged in low involvement shopping situations are not likely to be aware of their satisfaction due to the lack of motivation and/or ability to evaluate the store. In such case, customers tend not to elaborately compare the expectations of store image and store performance. However, when customers shop for high-involvement products, they elaborate on the evaluation of a store, compare their expectations and store performances, and form store loyalty only when perceived performances meet or exceed their prior expectations [57]. When it is the case of high involvement products, expectations formed by store image only can influence store loyalty through a satisfaction [58]. Therefore, future research should consider satisfaction as an antecedent of store loyalty, especially when they include high involvement products in the study.

In the present study, the impacts of store size were analyzed through group comparisons between small and large stores. The test results indicated that the effects of pleasure on expectation, and expectation on store loyalty between the two stores were significantly different. However, we cannot tell from the results that which effects are more significant than others. Thus, investigating the linear relationship between store size and spatial crowding could be a meaningful topic for future research.

\section{REFERENCES}

[1] Kotler, P. 1973. Atmospherics as a marketing tool. Journal of Retailing, 49(4), 48-64.

[2] Li, J. T., Kim, J., \& Lee, S. Y. 2009. An empirical examination of perceived retail crowding, emotions, and retail outcomes. The Service Industries Journal, 29(5), 635-652.

[3] Levy, M., \& Weitz, B. A. 2001. Retailing management (4th ed). New York: McGraw Hill.

[4] Stokols, D. 1972. On the distinction between density and crowding: Some implications for future research. Psychological Review, 79(3), 275-277.

[5] Eroglu, S. A., \& Machleit, K. A. 1990. An empirical study of retail crowding: Antecedents and consequences. Journal of Retailing, 66, 201-221.

[6] Machleit, K. A., Kellaris, J. J., Eroglu, S. A. 1994. Human vs. spatial dimensions of crowding perceptions in retail environments: A note on their measurement and effect on shopper satisfaction. Marketing Letters, 5, 183-194.

[7] Machleit, K. A., Eroglu, S. A., \& Mantel, S. P. 2000. Perceived retail crowding and shopping satisfaction: What modifies this relationship? Journal of Consumer Psychology, 9(1), 29-42.

[8] Dion, D. 2004. Personal control and coping with retail crowding. International Journal of Service Industry Management, 15(3), 250-263.
[9] Eroglu, S. A., Machleit, K. A, \& Barr, T. F. 2005. Perceived retail crowding and shopping satisfaction: the role of shopping values. Journal of Business Research, 58, 1146-1153.

[10] Berman, B. \& Evans, J. R. 2009. Retail Management: A Strategic Approach. Prentice Hall, Pearson, 358-360.

[11] Desor, J. A. 1972. Toward a psychological theory of crowding. Journal of Personality and Social Psychology, 21(1), 79-83.

[12] McClelland, L. \& Auslander, N. 1978. Environment and Behavior, 10(4), 535-553.

[13] Harrell, G. D., Hutt, M. D., \& Anderson, J. C. 1980. Path analysis of buyer behavior under conditions of crowding. Journal of Marketing Research, 17, 45-51.

[14] Hui, M. K., \& Bateson, J. E. G. 1991. Perceived control and the effects of crowding and consumer choice on the service experience. Journal of Consumer Research, 18, 174-184.

[15] Rapport, A. 1975. Toward a redefinition of density. Environment and Behavior, 7(2), 133-158.

[16] Gardner, M. P. 1985. Mood states and consumer behavior: A critical review. Journal of Consumer Research, 12, 281-300.

[17] Holbrook, M. B., \& Brata, R. 1987. Assessing the role of emotions as mediators of consumer responses to advertising. Journal of Consumer Research, 14, 404-420.

[18] Mehrabian, A., \& Russell, J. A. 1974. An approach to environmental psychology. Cambridge, MA: MIT press.

[19] Donnovan, R. J., \& John,R. R. 1982. Store atmosphere: An environmental psychology perspective. Journal of Retailing, 58(Spring), 34-57.

[20] Oliver, R. L. 1980. A cognitive model of the antecedents and consequences of satisfaction decisions. Journal of Marketing Research, 17, 460-469.

[21] Boulding, W., Kalra, A., Staelin, R., \& Zeithamal, V. A. 1993. A dynamic process model of service quality: from expectations to behavioral intentions. Journal of Marketing Research, 30(1), 7-27.

[22] Pham, M. T., Cohen, J. B., Pracejus, J. W., \& Hughes, G. D. 2001. Affect monitoring and the primacy of feelings in judgement. Journal of Consumer Research, 28, 167-188.

[23] Jacoby, J. \& Chestnut, R. W. 1978. Brand Loyalty: Measurement and Management. New York, John Wiley and Sons.

[24] Odekerken-Schroder, G., Wulf, K. D., Kasper, H., Kleijnen, M., Hoekstra, J., \& Commandeur, H. 2001. The impact of quality on store loyalty: A contingency approach. Total Quality Management, 12(3), 302-322.

[25] Macintosh, G. \& Lockshin, L. S. 1997. Retail relationships and store loyalty: A multi-level perspective. International Journal of Research in Marketing, 14, 487-497.

[26] Dick, A. S. \& Basu, K. 1994. Customer loyalty: Toward an integrated conceptual framework. Journal of the Academy of Marketing Science, 22, 99-113.

[27] Engel, J. F., Blackwell, R. D., \& Miniard, P. W. 1995. Consumer Behavior. Fort Worth, The Dryden Press. 
[28] Dachyar, M. \& Fatkhurrohman. 2011. The effect of innovation factors to customer loyalty by structural equation model. World Academy of Science, Engineering and Technology, 5, 712-716.

[29] Cadwallader, M. 1975. A behavioral model of consumer spatial decision making. Economic Geography, 51(4), 339-349.

[30] White, R. 1959. Motivation reconsidered - the concept of competence. Psychological Review, 66, 297-333.

[31] Thompson, S. 1981. Will it hurt less if I can control it? A complex answer to a simple question. Psychological Bulletin, 90(1), 89-101.

[32] Proshansky, H. M., William, H. I., \& Leanne, G. R. 1974. "Freedom of choice and behavior in a physical setting" in environmental psychology, ed.

[33] Miller, S. M. 1979. Controllability and human stress: Method, evidence, and theory. Behaviour Research and Therapy, 17(4), 287-304.

[34] Bateson, J. E. 1985. Self-service consumer: An explanatory study. Journal of Retailing, 61(3), 49-76.

[35] Baum, A., Fisher, J., \& Solomon, S. K. 1981. Type of information, familiarity, and the reduction of crowding stress. Journal of Personality and Social Psychology, 40(1), 11-23.

[36] Baum, A., \& Valins, S. 1977. Architecture and social behavior: psychological studies of social density, New York: Wiley.

[37] Baker, J., Parasuraman, A., Grewal, D., \& B. Voss, G. 2002. The influence of multiple store environment cues on perceived merchandise value and patronage intentions. Journal of Marketing, 66, 120-141.

[38] Lehn, D. V. 2006. Embodying experience. European Journal of Marketing, 40(11/12), 1340-1359.

[39] Shrum, W., Duque, R., \& Brown, T. 2005. Digital video as research practice: Methodology for the millennium. Journal of Research Practice, 1(1), 1-19.

[40] Baker, J., Levy, M., \& Grewal, D. 1992. An experimental approach to making retail store environmental decisions. Journal of Retailing, 68(4), 445-460.

[41] Bateson, J. G., \& Hui, M. K. 1992. The ecological validity of photographs slides and videotapes in simulating the service setting. Journal of Consumer Research, 19(2), 271-281.

[42] Gagliano, K. B. \& Hathcote, J. 1994. Customer expectations and perceptions of service quality in retail apparel specialty stores. Journal of Services Marketing, 8(1), 60-69.

[43] Ellis-Reynolds, K. \& Beatty, S. E. 1999. Customer benefits and company consequences of customer-salesperson relationships in retailing. Journal of Retailing, 75, 11-32.
[44] Sirohi, N., McLaughlin, E. W., \& Wittink, D. R. 1998. A model of consumer perceptions and store loyalty intentions for a supermarket retailer. Journal of Retailing, 74, 223-245.

[45] Langer, E. J., \& Saegert, S. 1977. Crowding and cognitive control. Journal of Personality and Social Psychology, 35(3), 175-182.

[46] Anderson, J. C., \& Gerbing, D. W. 1988. Structural equation modeling in practice: A review and recommended two-step approach. Psychological Bulletin, 103(3), 411-423.

[47] Baron, R. M., \& Kenny, D. 1986. The moderator-mediator variable distinction in social psychological research: Conceptual, strategic, and statistical considerations. Journal of Personality and Social Psychology, 51(6), 1173-1182.

[48] Bentler, P. M., \& Bonett, D. G. 1980. Significance tests and goodness of fit in the analysis of covariance structures. Psychological Bulletin, 88, 588-606.

[49] Chaikan, S. 1980. Heuristic versus systematic information processing and the use of source versus message cues in persuasion. Journal of Personality and Social Psychology, 39(5), 752-766.

[50] Altman I. 1975. The environment and social behavior: privacy, personal space, territory and crowding. Monterey (CA): Brooks and Cole.

[51] Mittal, B., \& Lee, M. 1989. A casual model of consumer involvement. Economic Psychology, 10(3), 363-389.

[52] Dholakia, U. M. 1998. Involvement-response models of joint effects: An empirical test and extension. Advances in Consumer Research, 25, 499-506.

[53] Celsi,R. L., Jerry, C. O. 1988. The role of involvement in attention and comprehension processes. Journal of Consumer Research, 15(20, 210-224.

[54] Suh, J., \& Yi, Y. 2006. When brand attitudes affect the customer satisfaction-loyalty relation. Journal of Consumer Psychology, 16(2), 145-155.

[55] Petty, R. E., \& Cacioppo, J. T. 1986. The elaboration likelihood model of persuasion. Advances in Experimental Social Psychology, 19, 123-205.

[56] Blemer, J. M. M., \& Poisez, T. B. C. 1989. The illusion of consumer satisfaction. Journal of Consumer Satisfaction, Dissatisfaction, and Complaining Behavior, 2, 43-48.

[57] Bitner, M. J. 1990. Evaluating service encounters: The effects of physical surroundings and employee responses. Journal of Marketing, 54, 69-82.

[58] Bloemer, J., \& Ruyter, K. 1998. On the relationship between store image, store satisfaction, and store loyalty. European Journal of Marketing, 32(5/6), 499-513. 